\title{
CONTRACTILE RESPONSES OF ISOLATED CANINE: BLOOD VESSELS TO ATP AND ADP
}

\author{
IUro UEDA and Yumiko OHTAKI \\ Deparment of Plarmacology, Teikyo Univerwiry \\ School of Medicine, Itabashi-k,t. Tok 1o 173, Japan \\ Accepted octiber 14. 1976
}

\begin{abstract}
Effects of ATP and $\triangle D P$ on helically cul strips of canine different blood vessels were studied, in comparison with those of $K$ and norepinephrine (N.E.). ATP and ADP were equally effective in causing transient contractions in contrast to sustained contractions induced by $K^{\prime}$ and N.F.. The mesenterie, renal arteries and portal vein were sensitive wo both nucteotides. The response to the nucleotides and $k$ was more dependent on $\mathrm{Ca}^{\prime}$ and $\mathrm{Mg}^{2}$ concentrations in bathing media than that to N.L.. Treatment of the strips with EGTA in $\mathrm{Ca}^{-r}$-free media quickly abolished the contractile responses to ATP, ADP and $\mathrm{K}$. Application of $0.1 \mathrm{mM} \mathrm{Cd}^{*}$ attenuated the contractik responses to $\mathrm{K}$ more markedly than those to $\mathrm{N}$.E., but did not affect $A T P$ action. Verapamil at $0.5, \mathrm{M}$ inhibited the $\mathrm{K}$-induced contraction alone, and $2 \mathrm{mM}$ procaine inhibited the response to N.E. alone, hut rather intensified the ATP-induced contraction. It may be concluded that ATP and ADP produce a transient contraction of isolated canine blood vessels by a mechanism relating to an increased mobilization of loosely bound Ca in cill membranes.
\end{abstract}

ATP and related compounds have been shown to produce a vasodilation in most vascular beds in situ, but to cause cither contraction or relaxation in a varicty of isolated blood vessels and at different vascular tones. ATP and ADP produced relaxing responses in strips of rabbit portal vein (1) and dog coronary and renal arteries (2), in contrast, contractile responses of strips of rabbit aorta $(3,4)$, ral portal vein (5), and isolated perfused rat renal artery (6) were observed. It has been reported that the contractile responses were modified by $\mathrm{Ca}^{+}$and $\mathrm{Mg}^{++}$concentrations in bathing media; an increase of $\mathrm{Ca}^{++}$: $\mathrm{Mg}^{++}$ratio enhanced contractile responses and a decrease of ratio vice versa $(5,6)$. However, the mechanism of contractile effects of ATP and ADP has not been elucidated.

In the present experiment, effects of ATP and ADP were studied in isolated different blood vessels of the dog and the mechanisms of their contractile effects were studied in comparison with those of $\mathrm{KCl}$ and norepinephrine, since the contractile mechanisms of both agents have been fairly well clarified $(7-10)$.

\section{MATERIALS AND MEIHODS}

Mongrel dogs of both sexes, weighing $10-15 \mathrm{~kg}$, were anesthetized with sodium pentobarbital and sacrificed by bleeding from the carotid arteries. The supcrior nesenteric, renal, coronary and femoral arteries and the mesenteric, portal and renal veins were isolated. Helical strips of approximately $15,3 \mathrm{~mm}$ were cut from these arteries and veins, and cach strip was fixed vertically between hooks under a resting tension of $1-2 \mathrm{~g}$ in a $20 \mathrm{ml}$ organ bath containing Krebs solution. Constituents of the solution were as follows (mM): $\mathrm{Na}^{+}$, 
143.5; K+, 5.9; $\mathrm{Cat}^{-+}, 2.5 ; \mathrm{Cl}^{--}, 125.8 ; \mathrm{HgPO}_{4}^{-}, 2.5 ; \mathrm{HCO}_{3}^{-}, 25.0$; dextrose, 5.0. The nutrient solution was maintained at $37 \mathrm{C}$ and aerated with a mixture of $95 \% \mathrm{O}_{2}$ and $5 \%$ CO. The $\mathrm{pH}$ of the soiution was 7.2-7.4. $\mathrm{Ca}^{++}$and $\mathrm{Mg}^{++}$concentrations of Krebs solution were changed as required. The strips were allowed to equilibrate for 90-120 min before experiments were commenced. In experiments using qualified Krebs solution, the strips were exposed to these solutions for 60 min, during the exposure period, the solution was replaced every $20 \mathrm{~min}$. EGTA (ethyleneglycol-bis-( $\beta$-aminoethylether) $\mathrm{N}, \mathrm{N}^{\prime}$-tetraacetic acid) was dissolved in $1 \mathrm{~N} \mathrm{NaOH}$ and added to $\mathrm{Ca}^{++}$-free solution at $1 \mathrm{mM}$. Preparations were exposed to EGTA-added, $\mathrm{Ca}^{++}$-free solution for 5 or $40 \mathrm{~min}$ and then to $\mathrm{Ca}^{++}$-free solution for 5 or $20 \mathrm{~min}$, respectively. The hook anchoring the upper end of strips was connected to the lever arm of a force-displacement transducer (Nihonkoden Kogyo Co., SB1TH). The contractile responses of strips to stimulatory agents were recorded on an inkwriting oscillograph (Nihonkoden Kogyo Co., PMP-3004). Response of each strip to each agent in nomal nutrient solution was taken as $100 \%$ and the response to the same concentration of the same agent after various treatments was expressed as $\%$ of controls. In most experiments, $30 \mathrm{mM} \mathrm{K}, 10^{-6}-2 \times 10^{-6} \mathrm{M}$ norepinephrine and $10^{-3}-3 \times 10^{-9} \mathrm{M} \mathrm{ATP}$ were used. Results shown in tables and figures are expressed as mean values $t$ standard errors of the means. Statistical analyses were made using the Student's $t$-test.

The agents used were potassium chloride ( $\mathrm{K}^{+}$, Wako Pure Chem.), dl-norepinephrine hydrochloride (N.E., Sankyo), adenosine triphosphate disodium (ATP, Kowa), adenosine diphosphate disodium (ADP, Kyowa Hakko), atropine sulfate (Tanabe Sejyaku), phentolamine hydrochloride (Ciba), phenoxybenzamine hydrochloride (Nikken Kagaku), diphenhydramine hydrochloride (Kowa), cadmium chloride ( $\mathrm{Cd}^{++}$, Wako Pure Chem.), procaine hydrochloride (proc, Daiichi Seiyaku) and verapamil hydrochloride (ver., Eisai).

\section{RESULTS}

Liffects of ATP and ADP on the strips of isolated different bluod vessels

Application of $3 \times 10^{-3} 10^{-2} \mathrm{M} \mathrm{ATP}$ and ADP to strips of the superior mesenteric and renal arteries of the dog produced dose-dependent contractions. Contractions which developed immediately after application of ATP and ADP reached a peak within 1 to 2 minutes, and were followed by relaxation to the original tension within 2 to 3 minutcs. In contrast, the sustained contraction, consisting of the initial phasic and successive tonic phase, was induced by $30-50 \mathrm{mM} \mathrm{K}+$ and $10^{-6}-10^{-5} \mathrm{M} \mathrm{N} . \mathrm{E}$. . ATP and ADP were about equally effective in causing contraction of each blood vessel (Fig. 1). Repeated applications of $10^{-3}-3 \times 10^{-3} \mathrm{M}$ ATP and ADP at $10 \mathrm{~min}$ intervals, during which time the prepara-

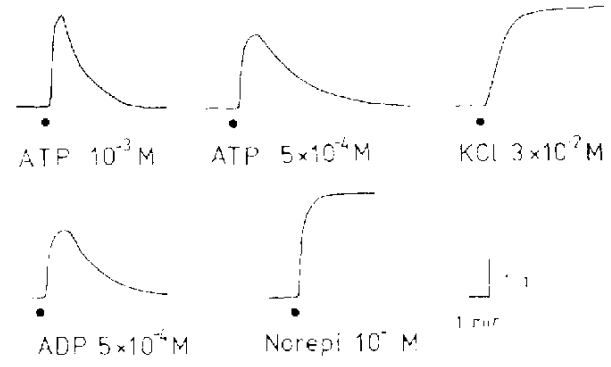

Fri. I. Contractile responses of the superior mesenteric arteries to $\mathrm{ATP}, \mathrm{ADP}, \mathrm{KCl}$ and norepinephrine. 
tions were washed with aerated nomal media, produced similar contractile effects. In the superior mesenteric and renal arteries and portal veins, the maximum contraction induced by $10^{-8} \mathrm{M}$ ATP and ADP was $75-85 \%$ of the contraction caused by $50 \mathrm{mM} \mathrm{K}$ and $10^{-5} \mathrm{M}$ V.E.. The minimum effective concentration of ATP and ADP was $3 \times 10^{-4} \mathrm{M}$ for coronary arteries and mesenteric veins, and $10^{-5} \mathrm{M}$ for the femoral arteries and renal veins, respectively. The maximum contraction induced by $10^{-2} \mathrm{M}$ ATP in the former two vessels was only one half the contraction seen in the mesenteric arteries, and that in the latter two vessels was one-third to one-fourth. The next experiments were carried out on strips of superior mesenteric arteries.

Effects of adrenergic and cholinergic blockers and antihistaminics on ATP and ADP contraction

The contractile effects of $10^{-3}-3 \times 10^{-3} \mathrm{MATP}$ and ADP on the vascular strips were not significantly inhibited by treatment with phentolamine $\left(10^{-6}-10^{-5} \mathrm{M}\right)$, phenoxybenzamine $\left(5 \times 10^{-5} \mathrm{M}\right)$, atropine $\left(10^{-5}, \mathrm{M}\right)$ and diphenhydramine $\left(10^{-6} \mathrm{M}\right)$. Each of these blockers at the above concentrations suppressed the contraction induced by the corresponding agonist, N.E. $\left(2 \times 10^{-6} \mathrm{M}\right)$, acetylcholine $\left(10^{-5} \mathrm{M}\right)$ and histamine $\left(10^{-5} \mathrm{M}\right)$.

Effects of $\mathrm{Ca}^{++}$and $\mathrm{Mg}^{++\cdots}$ on $A T P_{-}, A D P_{-}, \mathrm{K}^{+}$- and N.E.-contraction

Decrease in external $\mathrm{Ca}^{1}$ from 2.5 to $0.5 \mathrm{mM}$ attenuated the maximal contraction induced by $10^{-3}-3 \times 10^{-3} \mathrm{M}$ ATP and ADP to $60.5+3.2 \%(\mathrm{~N}=5)$ the control contraction, and the contraction induced by $30 \mathrm{mM} \mathrm{K}+$ to $51.6-7.7 \%(\mathrm{~N}-8)$, while such decrease in $\mathrm{Ca}^{++}$failed to significantly reduce the contractile effects of N.E. (Fig. 2). Removal of $\mathrm{Ca}^{++}$from the bathing media produced a further reduction in the contractile responses to

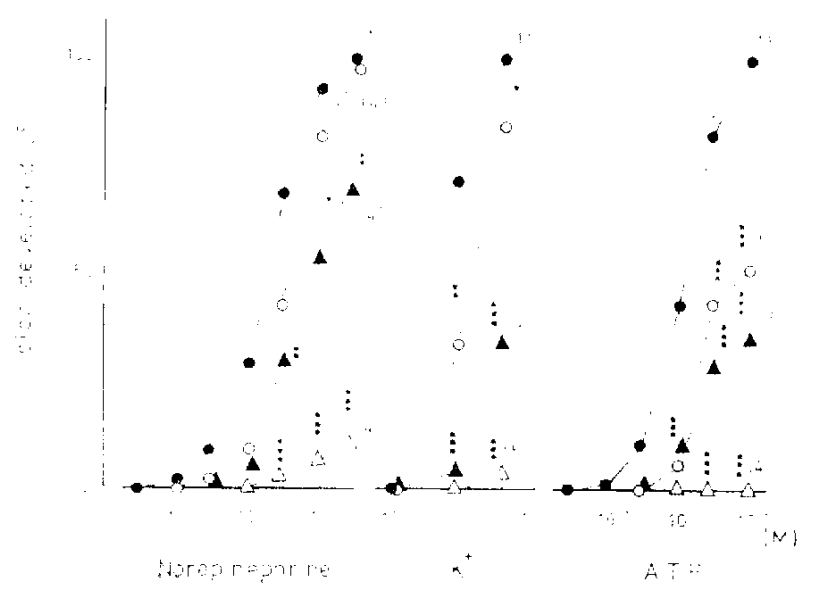

Fici. 2. Effects of loweting Ca t concentrations on the contractile responses of superior mesenteric arteries to norepinephrine, $\mathrm{K}^{+}$and $\mathrm{ATP}$. normal $\mathrm{Ca}^{++}$media (2.5 mM), low $\mathrm{Ca}^{-}$media $(0.5 \mathrm{mM}), \Delta$ A $\mathrm{Ca}^{++}$-free media, $\triangle-\triangle$ EGTA-added, $\mathrm{Ca}$-free media. The tension developed at $3: 10^{-5} \mathrm{M}$ norepinephrine, $5: 10^{-2} \mathrm{M} \mathrm{K}$ and $10^{-2} \mathrm{M}$ ATP in normal media was taken as $100 \%$ for each agent. *; Signiticant difference from values of the developed tension in nomal media, $p<0.01$, * ; $p<0.005,{ }^{*} ; p<0.001$. Figures in parentheses indicate number of preparations used. 


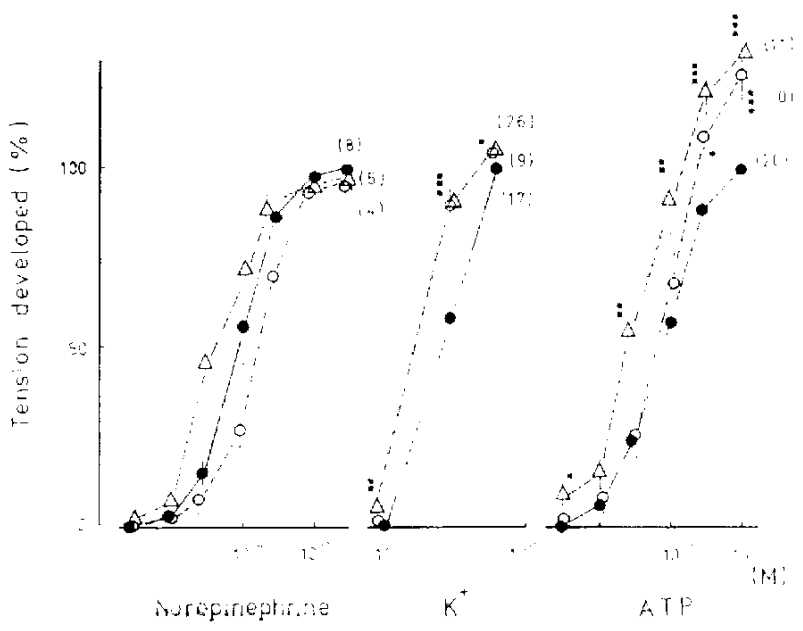

Fig. 3. Effects of high $\mathrm{Ca}^{+1}$ and $\mathrm{Mg}^{+1}$-free on the contractile responses of the superior mesenteric arteries to norepinephrine, $\mathrm{K}^{+}$and ATP. - normal media, $O$ high $\mathrm{Ca}^{+*}$ media $\left(\mathrm{Ca}^{++} 5.0 \mathrm{mM}\right), \triangle^{--} \Delta \mathrm{Mg}^{++}$-free media. The tension developed at $3 \times 10^{-5} \mathrm{M}$ norepinephrine, $5 \times 10^{-2} \mathrm{M} \mathrm{K}$ and $10^{-2} \mathrm{M}$ ATP in normal media was taken as $100 \%$ for each agent. *; Significant difference from values of the developed tension in normal media, $p<0.01$, **; $\mathrm{p}<0.005, * * *: \mathrm{p}<0.001$. Figures in parentheses indicate number of preparations used.

high concentrations of ATP and ADP as well as $\mathrm{K}^{+}$, shifting their dose-response curves to the right and downward, and a moderate reduction $(30.9 \pm 9.4 \%, \mathrm{~N}=4)$ in the response to N.E.. Treatment with $1 \mathrm{mM}$ EGTA for $5 \mathrm{~min}$ in $\mathrm{Ca}^{++}$-free media abolished the contractile responses of the strips to $10^{-3}-3 \times 10^{-3} \mathrm{M} \mathrm{ATP}$ and ADP also to $30 \mathrm{mM} \mathrm{K}$, but decreased to a lesser extent the response to $2 \times 10^{-6} \mathrm{M}$ N.E. $(80.8 \pm 7.7 \%, \mathrm{~N}=6)$. Further inhibition in the contractile responses was induced by treatment with EGTA for 40 min. Increase of external $\mathrm{Ca}^{++}$to $5 \mathrm{mM}$ significantly enhanced the maximum contraction induced by $3 \times 10^{-3}$ $10^{-2} \mathrm{M} \mathrm{ATP}$ and ADP, and shifted their dose-response curves to the left and upward (Fig. 3). Similar potentiation of the effect of $\mathrm{K}^{+}$was also demonstrated, while the dose-response curve of N.E. was not significantly altered.

Doubling the concentration of external $\mathrm{Mg}^{++}$had no significant influence on the effects of these four agonists. Further increase in $\mathrm{Mg}^{++}$to 4-fold the normal inhibited the contractile responses to both nucleotides $(31.5+6.9 \%, \mathrm{~N}=5)$ and $\mathrm{K}^{+}(55.3+10.6 \%, \mathrm{~N}=5)$, but did not significantly alter the N.E.-induced contraction. Removal of $\mathrm{Mg}^{++}$from normal media shifted dose-response curves for ATP, ADP and $\mathrm{K}^{+}$to the left and upward, but failed to alter the dose-response curve of N.E.. Removal of both $\mathrm{Ca}^{++}$and $\mathrm{Mg}^{++}$from the media reduced the contractile responses to these agonists to a lesser extent than those observed in $\mathrm{Ca}^{++}$-free solution.

Effecrs of ATP, ADP, $\mathrm{K}^{+}$and N.E. after addition of $\mathrm{Ca}^{++}$to EGTA-added, $\mathrm{Ca}^{++}$-free media

Although the application of $\mathrm{Ca}^{++}(2.5 \mathrm{mM})$ to the strips, which had been exposed to EGTA-added, $\mathrm{Ca}^{++}$-free media for $40 \mathrm{~min}$, caused no contraction, the simultaneous ap- 
TABLL 1. Effects of ATP, $\mathrm{K}^{+}$and norepinephrine (N.E.) after addition of Ca to EGTAadded, $\mathrm{Ca}{ }^{+}{ }^{+}$-free media

\begin{tabular}{|c|c|c|c|c|c|c|c|c|c|}
\hline Agonists & АТP 3 & $10^{-3} \mathrm{M}$ & & $\mathrm{K}^{+} 3$ & $10^{-2} \mathrm{M}$ & & N.E. $\quad 2$ & $10^{-6} \mathrm{M}$ & \\
\hline$t$ & Гension (g) & $\%$ & $n$ & Tension $(\mathrm{g})$ & $\%$ & $n$ & Tension $(\mathrm{g})$ & $\%$ & $\mathrm{n}$ \\
\hline Control & $1.67 \therefore 0.09$ & 100 & 31 & $2.03=0.09$ & 100 & 4 & $2.38 \pm 0.28$ & 100 & 11 \\
\hline $0 \mathrm{~min}$ & $1.28=0.19 *$ & 76.6 & 14 & $2.18=0.23$ & 107.4 & 4 & $2.55 \div 0.38$ & 107.1 & 4 \\
\hline 1.0 & $1.49 \div 0.20$ & 89.2 & 7 & - & & & $\ldots$ & & \\
\hline 2.0 & $1.52: 0.12$ & 91.0 & 6 & - & & & $2.59 \div 0.36$ & 108.8 & 6 \\
\hline 3.0 & $1.83=0.28$ & 109.6 & 3 & -- & & & & & \\
\hline
\end{tabular}

Contractile responses of the superior mesenteric arteries to ATP, $K$ and norepincphrine (N.E.) after $\mathrm{Ca}^{++}(2.5 \mathrm{mM})$ application with lapse of time between addition of each agent and $\mathrm{Ca}^{\cdots}$. Tension developed in normal media was taken as $100 \%$ for each agent. n; Number of preparations used. $t$ : Time interval between applications of $\mathrm{Ca}^{++}$and each agent. *: Significant difference from value of the developed tension in normal media, $\mathrm{p}<0.05$.

plication of $3 \times 10^{-3} \mathrm{MATP}$ with $\mathrm{Ca}^{++}$produced a transient contraction, the magnitude being significantly less than that induced by ATP in normal media. ATP when added 3 min after the application of $\mathrm{Ca}^{++}$caused a transient contraction which was almost the same as that seen in control media. Similar responses were observed after application of ADP. On the other hand, contractile responses to $\mathrm{K}^{+}$and N.E. were not influenced when $\mathrm{Ca}^{++}$ $(2.5 \mathrm{mM})$ was added after long exposure of the strips to EGTA-added, Ca ${ }^{++}-$free media (Table 1).

Effects of $C^{++} d^{+}$, ver and proc. on $A T P-, K^{+}-$and $N$. E.-contraction

Treatment of mesenteric arterial strips with $0.02 \mathrm{mM} \mathrm{Cd}^{++}$for 20 min slightly inhibited the contractile response to $30 \mathrm{mM} \mathrm{K}^{+}$, and did not alter the response to $10^{-6} \mathrm{M} \mathrm{N}$.E. and $3 \times 10^{-3} \mathrm{M} \mathrm{ATP}$. The addition of $0.1 \mathrm{mM} \mathrm{Cd}^{\prime \prime}$ markedly decreased the response to $\mathrm{K}^{+}$, but only slightly reduced the response to N.E. At this concentration of $\mathrm{Cd}^{++}$, the response to ATP was not influenced (Table 2). When preparations were exposed for 20 min to ver. in a concentration of $5 \times 10^{-7} \mathrm{M}$. contractions produced by $30 \mathrm{~m} \mathrm{M} \mathrm{K}+$ decreased to $47.0_{+}$ $5.6 \%(\mathrm{~N}=8)$ of control, whereas the contractions caused by $10^{-6} \mathrm{M} \mathrm{N}$.E. and $10^{-3} \mathrm{M}$ ATP were not significantly altered. Treatment for $5 \mathrm{~min}$ with $2 \mathrm{mM}$ proc. suppressed the contractile response to $10^{-6} \mathrm{M}$ N.E., but did not change the contraction induced by $30 \mathrm{mM}$ $\mathrm{K}^{+}$. ATP-induced contraction was rather enhanced by proc. (Table 2 ).

\section{DISCUSSION}

The present study showed that ATP and ADP were equally effective in causing con- 


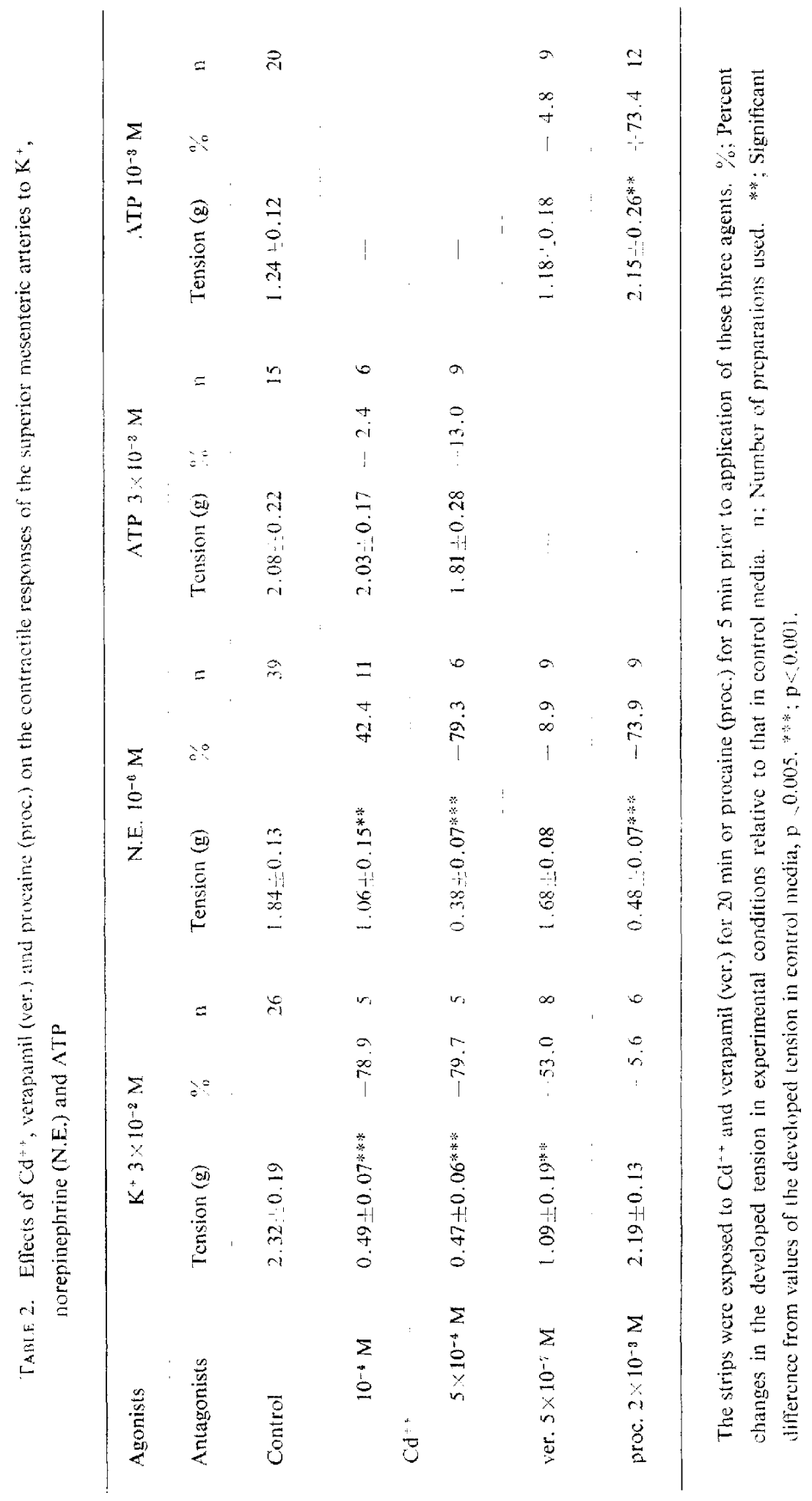


traction of isolated different blood vessels of the dog. Among the blood vessels tested, the supcrior mesenteric and renal artery and portal vein showed relatively high responses to both nucleotides. However, the maximun contraction induced by both nucleotides in these blood vessels was smaller than that induced by $50 \mathrm{mM} \mathrm{K} \mathrm{K}^{+}$and $10^{-5} \mathrm{M} \mathrm{N.E.}$. The contractions induced by ATP and ADP were quite different from those caused by $\mathrm{K}^{+}$and N.E.: both nuclcotides produced a transient contraction, while $\mathrm{K}^{+}$and N.E. produced a sustained contraction. On the basis of the phasic pattern of contraction, it is suggested that the nucleotide-induced contraction is due to release of membrane bound and intracellularly stored $\mathrm{Ca}^{1+}(11)$.

The contractile responses of the mesenteric arterial strips to ATP and ADP were not influenced by adrenergic, cholinergic blockers and antihistaminics as reported in the isolated perfused rat renal artery (6) and the rat portal vein (5). These data indicate that the effects of ATP and ADP are not related to the transmitter release but rather to their dircet action on the smooth muscle of blood vessels.

The contractile responses of isolated mesenteric arterial strips to ATP and ADP were closely related to $\mathrm{Ca}^{++}$and $\mathrm{Mg}^{++}$concentrations in bathing media; high $\mathrm{Ca}^{++}: \mathrm{Mg}^{++}$ratio favoring contraction, and low ratio opposing contraction as evidenced in the rat portal vein (5) and the isolated rat renal artery (6). Especially, the response to the nucleotides and $\mathrm{K}^{+}$was more susceptible to removal of $\mathrm{Ca}^{++}$than that with N.E.. Such different susceptibility in the response to $\mathrm{K}^{+}$and N.E. has been reported by other workers (12-15). Thus $\mathrm{Ca}^{++}$available for the nucleotide-induced contraction may be supplied from external fluids across cell membranes and also from intracellular stored sites as shown in $\mathrm{K}^{+}$-induced contraction $(12,13)$. However, as described above it has been postulated that the transient contraction is associated with a release of membrane bound and intracellulary stored $\mathrm{Ca}^{\mathrm{i}+}$ (11), whereas the tonic contraction is associated with a sustained increase in the $\mathrm{Ca}^{+--}$ influx $(7,9)$. In the present experiment, it was confirmed that the simultaneous application of $\mathrm{Ca}^{++}$with ATP to the strips, which had been exposed to EGTA-added, $\mathrm{Ca}^{++}$-free media, produced a contraction smaller than that induced by ATP in normal media, but the same maneuver with $\mathrm{K}^{+}$or $\mathrm{N}$.E. elicited a contraction as large as that which occurred in normal media. These findings suggest that the $\mathrm{Ca}^{+}+$-influx is not mainly related to ATP- and ADPinduced contraction. Recently, Toda (15) demonstrated that $\mathrm{Cd}^{++}$suppresses vascular contractions in response to stimulatory agents, including $\mathrm{K}^{+}$, N.E., histamine ctc., by interference with $\mathrm{Ca}^{++}$-influx. The present experiments showed that $\mathrm{Cd}^{++}$attenuated the contractile responses to vascular strips to $\mathrm{K}^{+}$more markedly than that to N.E., and this divalent cation failed to inhibit the ATP-induced contraction. Verapamil was also effective in inhibiting the $\mathrm{K}^{+}$-induced contraction, but ineffective in attenuating the contractions induced by N.E. (17) and ATP. These results support the idea that the contractile response to ATP is not ascribable to an increased $\mathrm{Ca}^{++}$-influx but to a release of stored $\mathrm{Ca}^{++}$.

Proc. did not inhibit ATP-induced contraction but rather intensified it. While the contractile response to N.E. was suppressed by proc. the response to $\mathrm{K}^{+}$was not modified, the findings being in agreement with Hudgins and Weiss" report (13). These authors demon- 
strated a specific antagonism of proc. to N.E.-induced contraction by preventing Cat"release from firmly bound stores. These findings suggest that ATP-induced transient contraction is not associated with firmly bound $\mathrm{Ca}^{++}$-stores. On the other hand, it has been reported that part of $\mathrm{Ca}^{++}$available for $\mathrm{K}^{+}$-induced contraction must be loosely-bound $\mathrm{Ca}^{++}$with cell membrane, since it is rapidly depleted by EDTA or removal of external $\mathrm{Ca}^{+}$. $(12,13)$. This may be true with both nucleotides since EGTA rapidly abolished the contractions.

From these studies, it may be concluded that ATP and ADP caused a transient contraction of isolated canine blood vessels by a mechanism related to an increased mobilization of loosely bound $\mathrm{Ca}^{++}$in cell membranes.

Acknowledgement: We are grateful to Prof. N. Toda for pertinent discussion.

\section{REFERENCES}

1) Hughes, J. and Vane, J.R.: Brit. J. Pharmacol. 30, 46 (1967)

2) Walter, P. and Bassenge, E.: Pflügers Arch. 299, 52 (1968)

3) Furchgort, R.F.: Bull. N.Y. Acad. Med. 42, 996 (1966)

4) Iso, T., Yamalchi, H., UdA, K. ANd Toshioka, N.: Japan. J. Pharmacol. 21, 393 (1971)

5) Siöberg, B. and Wahlstrom, B.A.: Acta physiol. scand. 94, 46 (1975)

6) Hrdina, P.E., Bonaccorsi, A. And Benvenuti, F.: Europ. J. Pharmacol. 12, 249 (1970)

7) Briggs, A.H.: Am. J. Physiol. 203, 849 (1962)

8) Axelsson, J., Wohlstrom, B., Johaysson, B. and Jonsson, O.: Circulation Res. 21, 609 (1967)

9) BOHR, D.F.: Science 139, 597 (1963)

10) Deth, R. And van Breemen, C.: Pflügers Arch. 13, 348 (1974)

11) Somlyo, A.V. and Somlyo, P.S.: J. Pharmacol. exp. Ther. 159, 129 (1968)

12) Hinke, J.A.M.: Muscle, Edited by Pall, W.M., Daniel, E.E., Kay, C.M. and Monckton, G., p. 269, Pergamon Press, New York (1965)

13) Hudgins, P.M. And Weiss, G.B.: J. Pharmacol exp. Ther. 159, 91 (1968)

14) Hiraoka, M., Yamaguchi, S. and Sano, T.: Am. J. Physiol. 214, 1048 (1968)

15) Toda, N.: Am. J. Physiol. 225, 350 (1973)

16) Sitrin, M.D. And Bohr, D.F.: Am. J. Physiol. 220, 1124 (1971)

17) Peiper, U., Grifbel, L. And Wende, W.: Pflïgers Arch. 330, 74 (1971) 